Endocrinol. Japon., Vol. 3, No. 1 (1956).

\title{
INFLUENCE OF MESOXALATE AND VARIOUS HORMONES ON GARBOHYDRATE METABOLISM IN RAT LIVER SLICES (IN VITRO)
}

\author{
ROKURO NAKAI \\ Department of Internal Medicine, II Division, Kobe Medical College, Kobe \\ (Chief, Prof. M. Takeda)
}

A recent report by Baba of this laboratory (1956) on the effects of mesoxalate and various hormones upon the glucose uptake and glycogen formation in isolated diaphragms showed the interesting findings that the normal surviving rat diaphragm can synthesize a marked amount of glycogen from glucose when insulin or cortisone were previously administered, and also that an increased formation of glycogen was found in the alloxan diaphragm with a previous administration of mesoxalate, while a pretreatment with ACTH or DOCA showed no change.

Ostern, Herbert and Holmes (1939) first demonstrated that liver slices can synthesize glycogen in vitro from added glucose; later, the important condition for the glycogen formation in the liver slices was pointed out by Buchanan and Hastings (1949) that the glycogen formation in liver slices took place only in a specific ionic environment of the incubating medium.

According to the report of Baba, more definite changes in the ability of the synthesis of glycogen in isolated diaphragm was found in the animals previously treated, with mesoxalate or various hormones, than the direct application of those substances to the medium in which the tissue slices were immersed. Almost all the informations available were referred to the effects of hormones when added into the medium, but, as far as the pretreatment with the hormones in surviving tissues is concerned, few reports are available (Seckel, 1940; Bendell and Lehmann, 1942; Chiu and Needham, 1950; Chiu, 1950). The present experiment was undertaken, using the liver slices, to study the effects on the glycogen synthesis of pretreatment of animals with mesoxalate and various hormones under the ionic composition of glycogenolytic and glycogenetic conditions in normal and alloxan diabetic rat; the effects of some hormones or mesoxalate added into the medium were also investigated.

\section{EXPERIMENTAL METHOD}

\section{1) Preparation of tissue}

Rats, weighing 100-120 gm, fasted for 24 hours before the experiment, were killed by head blow. It should be mentioned here that, as the glycogen content of the liver played very

Received for publication March 10, 1956. 
important part in these experiments, it was most desirable to put the animals in fasting condition for 24 hours. The liver was taken out carefully and quickly, and was cut into $0.3 \sim 0.5$ $\mathrm{mm}$ thick slices by free-hand. Each slice was weighed by a torsion balance and somewhere about $200 \mathrm{mg}$ of slices were placed into a Warburg's flasks, where $2 \mathrm{ml}$ of ice-cold experimental medium was added. One of the flasks filled with an appropriate amount of glucose buffer solution was served as the control and the others were used for the test medium, containing various substances in question with glucose.

2) Condition of the medium and incubation

The flasks containing the tissue were placed in a bath at $37^{\circ} \mathrm{C}$, and after the equilibration was reached with a gas mixture of $5 \% \mathrm{CO}_{2}$ and $95 \% \mathrm{O}_{2}$, the flasks were shaken continuously for 1.5 hours by the Warburg's apparatus. Thereafter, the flasks were removed, cooled and the glycogen content of the liver slices and the amount of glucose in the medium were determined.

For the measurement of glycogen formation, the difference in glycogen contents between one test sample incubated for 1.5 hours and the other non-incubated one was used.

The value was expressed in mg per gm wet weight of slices. The madium used for the purpose of glycogenesis was the intracellular solution (the Buchanan and Hastings solution). The medium for glycogenolysis was the extracellular solution or the balanced salts solution B.S.S. due to Gey and Gey or Krebsringer bicarbonate solution (K. R. B.), and in all cases the initial $\mathrm{pH}$ was 7.4. The medium and the added substances into the medium were as follows:

(a) The medium:

Glucose..................200 mg \% (B.S.S.) or

$1 \%$ (Buchanan and Hastings solution)

Pyruvate ............... 0.4\% (Krebs-Ringer bicarbonate solution)

(b) The added substances:

Insulin $10^{-3}$ unit or 2 units per $\mathrm{ml}$

Adrenalin.................50 $\mathrm{gg}$ per $\mathrm{ml}$

Mesoxalate .............10.0, $50.0 \mathrm{mg}$ per $\mathrm{ml}$

Cortisone, DOCA or ACTH..........each $5 \mathrm{mg}$ per $100 \mathrm{ml}$

3) Chemical procedures

The glycogen determination of the liver slices was carried out by a modified method of those by Good, Kramer and Somogyi (1933), and Norikane (1942); the sugar value after the hydrolysis of precipitated glycogen and the quantity of glucose in medium was determined by Hagedorn-Jensen's method (1923; 1924).

4) Pretreatment of animals

Mesoxalate was orally administered to normal rats $100 \mathrm{mg}$ per kilo per day for 7 days.

ACTH, cortisone or DOCA, each $5 \mathrm{mg}$ per body weight per day, was injected to normal rats for 7 days. Alloxan diabetic rats were similarly treated with the above drugs for 4 days.

Normal rats were injected with adrenalin, $0.2 \mathrm{ml}$ of 1,000 times solution per kilo, or insulin, 3 units per kilo, and then were killed after 60 minutes.

\section{5) Production of diabetes}

Diabetes was induced by an intravenous injection of $50 \mathrm{mg}$ of alloxan per kilo of body weight. Animals in various stages of diabetes were used, varying from severe coma to latent stage which exhibited glucosuria only when carbohydrate-rich food was given.

\section{RESULTS}

1) Effect of mesoxalate on the glycogen synthesis by normal and alloxan rat liver slices 
(a) Effect of added mesoxalate into the medium

The results summarized in Tables $1 \& 2$ show the differences between the glucose, and glycogen contents before and after the incubation with the B.S.S. medium, into which glucose, glucose + mesoxalate, or glucos + mesoxalate + insulin were added.

Table 1. Carbohydrate utilization by liver slises from normal or alloxan diabetic rais in B.S.S. (mg per gm)

\begin{tabular}{|c|c|c|c|c|c|}
\hline & Medium & $\begin{array}{l}\text { Change of } \\
\text { Glucose }\end{array}$ & $\begin{array}{l}\text { Glucose } \\
\text { balance }\end{array}$ & $\begin{array}{l}\text { Glycogen } \\
\text { content }\end{array}$ & $\begin{array}{l}\Delta \\
\text { Glycogen }\end{array}$ \\
\hline \multirow{5}{*}{ 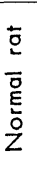 } & & & & 0,80 & 0 \\
\hline & B. S. S. & +2.07 & 0 & 0.54 & -0.26 \\
\hline & B. S. S. + Meso. $50 \mathrm{mg} \%$ & +2.09 & +0.02 & 0.49 & -0.31 \\
\hline & B. S. S. + Meso. $10 \mathrm{mg} \%$ & +2.09 & +0.02 & 0.52 & -0.28 \\
\hline & B. S. S. $+200 \mathrm{mg} \%$ Glucose & -0.04 & -2.45 & 0.55 & -0.25 \\
\hline \multirow{5}{*}{ 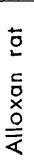 } & & & & 0.75 & 0 \\
\hline & B.S. S. & +2.16 & 0 & 0.45 & -0.30 \\
\hline & B. S. S. + Meso. $50 \mathrm{mg} \%$ & +2.20 & +0.04 & 0.42 & -0.33 \\
\hline & B. S. S. + Meso. $10 \mathrm{mg} \%$ & +2.25 & +0.09 & 0.40 & -0.35 \\
\hline & B. S. S. $+200 \mathrm{mg} \%$ Glucose & +0.36 & -1.80 & 0.48 & -0.27 \\
\hline
\end{tabular}

Medium $2 \mathrm{ml}$ : balanced salts solution (B. S. S.) and B. S. S. $+200 \mathrm{mg} \%$ glucose

Table 2. Carbohydrate utilizarion by liver slices from normal or alloxan diabetic rats ( $\mathrm{mg}$ per $\mathrm{gm}$ )

\begin{tabular}{|c|c|c|c|c|c|}
\hline & Medium & $\begin{array}{l}\text { Change of } \\
\text { Glucose }\end{array}$ & $\begin{array}{l}\text { Glucose } \\
\text { balance }\end{array}$ & $\begin{array}{l}\text { Glycogen } \\
\text { content }\end{array}$ & $\Delta \overrightarrow{G l y c o g e n}$ \\
\hline \multirow{8}{*}{$\begin{array}{l}\overline{0} \\
\overline{0} \\
\overline{0} \\
\overline{\mathbf{t}} \\
\bar{Z}\end{array}$} & & & & 0.72 & 0 \\
\hline & B. S. S. & +2.07 & 0 & 0.47 & -0.25 \\
\hline & G. B. S. S. & -1.99 & -4.06 & 0.50 & -0.22 \\
\hline & G. B. S. S. + Meso. $50 \mathrm{mg} \%$ & -2.24 & -4.31 & 0.52 & -0.20 \\
\hline & G. B. S. S. + Meso. $10 \mathrm{mg} \%$ & -2.47 & -4.54 & 0.49 & -0.23 \\
\hline & G. B. S. S. + Insulin $10^{-3} / \mathrm{ml}$ & -2.28 & -4.35 & 0.44 & -0.28 \\
\hline & $\begin{array}{l}\text { G. B. S. S. + Insulin + Meso. } \\
\quad 50 \mathrm{gm} \%\end{array}$ & -2.60 & -4.67 & 0.48 & -0.24 \\
\hline & $\begin{array}{l}\text { G. B. S. S. + Insulin + Meso. } \\
10 \mathrm{mg} \%\end{array}$ & -2.13 & -4.20 & 0.46 & -0.26 \\
\hline \multirow{8}{*}{ 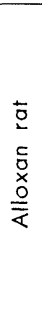 } & & & & 0.76 & 0 \\
\hline & B. S. S. & +4.65 & 0 & 0.47 & -0.20 \\
\hline & G. B. S. S. & +1.27 & -3.38 & 0.49 & -0.27 \\
\hline & G. B. S. S. + Meso. $50 \mathrm{mg} \%$ & +0.40 & -4.25 & 0.57 & -0.19 \\
\hline & G. B. S. S. + Meso. $10 \mathrm{mg} \%$ & +0.85 & -3.80 & 0.51 & -0.25 \\
\hline & G. B. S. S. + Insulin $10^{-3} / \mathrm{ml}$ & +1.39 & -3.26 & 0.42 & -0.34 \\
\hline & $\begin{array}{l}\text { G. B. S. S. + Insulin + Meso. } \\
50 \mathrm{mg} \%\end{array}$ & +1.25 & -3.40 & 0.45 & -0.31 \\
\hline & $\begin{array}{l}\text { G. B. S. S. + Insulin + Meso. } \\
10 \mathrm{mg} \%\end{array}$ & +1.45 & -3.20 & 0.41 & -0.35 \\
\hline
\end{tabular}

Medium $2 \mathrm{ml}: 200 \mathrm{mg} \%$ glucose tbalanced salts solution (G. B. S. S.)

The addition of mesoxalate or mesoxalate with insulin in various doses into the medium did not cause any definite differences on the glucose balance and glycogen formation before and after the incubation in normal and alloxan liver 
slices. However, in every case when glucose was added into the medium there were a definite amounts of disappearance of glucose and also the increased glycogen formation in normal and alloxan diabetic liver slices.

Further experiments were carried out in the same way as above described, but with the other ionic compositions and with the addition of pyruvate or glucose, i. e. K. R. B.+pyruvate for glycogenolysis and the Buchanan and Hastings solution+glucose for glycogenesis.

Table 3. Influence of adding mesoxalate into the medium normal or alloxan diabetic rat liver slices ( $\mathrm{mg}$ per $\mathrm{gm}$ )

\begin{tabular}{|c|c|c|c|c|c|c|}
\hline & & $\begin{array}{l}\text { Glucose } \\
\text { in a } \\
\text { medium }\end{array}$ & $\begin{array}{l}\text { Added insulin } \\
2 \mathrm{u} / \mathrm{ml} \text { in a } \\
\text { medium }\end{array}$ & $\begin{array}{l}\text { Initial } \\
\text { glycogen } \\
\text { content }\end{array}$ & $\begin{array}{l}\text { Decreased } \\
\text { glycogen } \\
\text { content }\end{array}$ & $\begin{array}{l}\text { Glycogen } \\
\text { change } \\
\%\end{array}$ \\
\hline \multirow{2}{*}{ Normal rat } & Control & $\begin{array}{l}3.22 \\
3.63\end{array}$ & $\begin{array}{l}(-) \\
(+)\end{array}$ & $\begin{array}{l}0.56 \\
0.56\end{array}$ & $\begin{array}{l}-0.15 \\
-0.14\end{array}$ & $\begin{array}{l}-26.8 \\
-25.0\end{array}$ \\
\hline & Meso. $50 \mathrm{mg} \%$ & $\begin{array}{l}3.76 \\
5.40\end{array}$ & $\begin{array}{l}(-) \\
(+)\end{array}$ & $\begin{array}{l}0.57 \\
0.57\end{array}$ & $\begin{array}{l}-0.19 \\
-0.18\end{array}$ & $\begin{array}{l}-33.3 \\
-31.6\end{array}$ \\
\hline \multirow{2}{*}{$\begin{array}{l}\text { Alloxan } \\
\text { diabetic rat }\end{array}$} & Control & $\begin{array}{l}4.56 \\
5.33\end{array}$ & $\begin{array}{l}(-) \\
(+)\end{array}$ & $\begin{array}{l}0.63 \\
0.63 \\
\end{array}$ & $\begin{array}{l}-0.28 \\
-0.26\end{array}$ & $\begin{array}{l}-44.4 \\
-41.3 \\
\end{array}$ \\
\hline & Meso. $50 \mathrm{mg} \%$ & $\begin{array}{l}5.10 \\
6.20\end{array}$ & $\begin{array}{l}(-) \\
(+)\end{array}$ & $\begin{array}{l}0.50 \\
0.50\end{array}$ & $\begin{array}{l}-0.18 \\
-0.17\end{array}$ & $\begin{array}{l}-38.0 \\
-34.0\end{array}$ \\
\hline
\end{tabular}

Glycogenolytic environment: medium $2 \mathrm{ml}, 0.4 \%$ pyruvate $+K$. R. B. solution

Table 4. Influence of adding mesoxalate into the medium norma: or alloxan diabetic rat liver slices ( $\mathrm{mg}$ per $\mathrm{gm}$ )

\begin{tabular}{|c|c|c|c|c|c|}
\hline & & $\begin{array}{l}\text { Glucose } \\
\text { in a } \\
\text { medium }\end{array}$ & $\begin{array}{l}\text { Initial } \\
\text { glycogen } \\
\text { content }\end{array}$ & $\begin{array}{l}\text { Increased or } \\
\text { decreased } \\
\text { glycogen cont. }\end{array}$ & $\begin{array}{l}\text { Glycogen } \\
\text { change } \\
\%\end{array}$ \\
\hline Normal & Control & -12.67 & 0.76 & +0.29 & +38.2 \\
\hline rat & Meso. $50 \mathrm{mg} \%$ & -13.10 & 0.76 & +0.35 & +46.1 \\
\hline Alloxan & Control & -3.05 & 0.76 & -0.29 & -38.2 \\
\hline rat & Meso. $50 \mathrm{mg} \%$ & -3.26 & 0.76 & -0.32 & -42.1 \\
\hline
\end{tabular}

Glycogenetic environment: medium $2 \mathrm{ml}, 1 \%$ glucose+Buchanan and Hastings solution

It would be explained from the Table 3 that under the environment of glycogenolysis, the glucose appearances into the medium are not much affected by the addition of mesoxalate alone into the medium, but the mesoxalate added with insulin caused certain increase of glucose appearances. For the glycogenolysis, mesoxalate caused hardly any change into the normal or alloxan diabetic animals.

Table 4 shows that when mesoxalate was added into the medium under the condition of glycogenesis, a slight increase of glycogen formation in normal liver slices was observed.

In alloxan diabetic liver slices, mesoxalate seemed not to cause any appreciable change.

(b) Effect of pretreatment with mesoxalate 
Table 5. Influences of mesoxalate pretreatmeni - normal or altoxan diabetic rat liver slices ( $\mathrm{mg}$ per $\mathrm{gm}$ )

\begin{tabular}{|c|c|c|c|c|c|c|c|}
\hline & & & $\begin{array}{l}\text { Glucose } \\
\text { in a } \\
\text { medium }\end{array}$ & $\begin{array}{l}\text { Added insulin } \\
2 \mathrm{u} / \mathrm{ml} \text { in a } \\
\text { medium }\end{array}$ & $\begin{array}{l}\text { Initial } \\
\text { glycogen } \\
\text { content }\end{array}$ & $\begin{array}{l}\text { Increased } \\
\text { or decreased } \\
\text { glycogen cont. }\end{array}$ & $\begin{array}{l}\text { Glycogen } \\
\text { change } \\
\%\end{array}$ \\
\hline \multirow{4}{*}{ 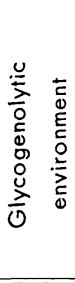 } & \multirow{4}{*}{$\frac{\overleftarrow{L}}{\bar{\sigma}}$} & Control & $\begin{array}{l}3.22 \\
3.63\end{array}$ & $\begin{array}{l}(-) \\
(+)\end{array}$ & $\begin{array}{l}0.56 \\
0.56\end{array}$ & $\begin{array}{l}-0.15 \\
-0.14\end{array}$ & $\begin{array}{l}-26.8 \\
-25.0\end{array}$ \\
\hline & & Meso. Pretreated & $\begin{array}{l}1.96 \\
0.03\end{array}$ & $\begin{array}{l}(-) \\
(+)\end{array}$ & $\begin{array}{l}0.60 \\
0.60\end{array}$ & $\begin{array}{l}-0.09 \\
-0.10\end{array}$ & $\begin{array}{l}-15.0 \\
-11.7\end{array}$ \\
\hline & & Control & $\begin{array}{l}4.56 \\
5.73\end{array}$ & $\begin{array}{l}(-) \\
(+)\end{array}$ & $\begin{array}{l}0.63 \\
0.63\end{array}$ & $\begin{array}{l}-0.28 \\
-0.26\end{array}$ & $\begin{array}{l}-44.4 \\
-41.3\end{array}$ \\
\hline & & Meso. Pretreated & $\begin{array}{l}2.50 \\
2.76 \\
\end{array}$ & $\begin{array}{l}(-) \\
(+)\end{array}$ & $\begin{array}{l}0.48 \\
0.48 \\
\end{array}$ & $\begin{array}{l}-0.07 \\
-0.05 \\
\end{array}$ & $\begin{array}{l}-14.6 \\
-10.4 \\
\end{array}$ \\
\hline \multirow{2}{*}{\multicolumn{2}{|c|}{ 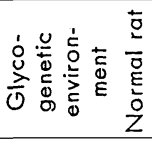 }} & Control & -12.67 & $(-)$ & 0.76 & +0.29 & +38.2 \\
\hline & & Meso. Pretreated & -10.6 & $(-)$ & 0.59 & +0.68 & +115.3 \\
\hline
\end{tabular}

Glycogenolytic environment: medium $2 \mathrm{ml}, 0.4 \%$ pyruvate + K. R. B. solution Glycogenetic environment: medium $2 \mathrm{ml}, 1 \%$ glucose + Buchanan and Hastings solution Pretreatment: mesoxalate per os $100 \mathrm{mg}$ per kilo for 7 days to normal rat and 4 days to alloxan rat

After mesoxalate was administered for seven days prior to the experiment as shown in Table 5, in the glycogenolytic environment, markedly decreased rates of appearance of glucose were seen in the medium added insulin with normal and alloxan rat liver slices. With the normal, more so with the alloxan liver slices, the glycogenolytic power was markedly inhibited as compared with control rat. Under the condition of glycogenesis, normal liver slices pretreated with mesoxalate showed a markedly increased formation of glycogen. (Table 5)

2) Effects of adrenalin or insulin on the synthesis of glycogen in normal and alloxan liver slices

(a) Under the environment of glycogenolysis

Insulin 2 units per $\mathrm{ml}$ or adrenalin $50 \mu \mathrm{g}$ per $\mathrm{ml}$ added to the medium, caused an increased appearance of glucose into the medium, and a decreased formation of glycogen by the addition of adrenalin and no change by insulin.

When insulin or adrenalin was injected prior to the experiment, the rates of appearance of glucose from the medium were diminished in both cases. No change on glycogen formation was observed in the liver slices of the previously injected insulin, however, a depressing effect on the glycogen synthesis was seen in the case of previously injected insulin (Table 6).

(b) Under the environment of glycogenesis

With the Buchanan and Hastings solution, and in the presence of $1 \%$ glucose in the incubating medium, a considerable amounts of glycogen were produced from glucose (Table 6). The same conditions with adrenalin or insulin injected prior to the experiment produced a large amounts of glycogen, and the latter was more effective than the former, however, no effect was observed when the insulin was added to the medium. 
Table 6. Influences of adrenalin or insulin added into the medium, and of pretreatment with these hormones - normal rat liver slices (mg per gm)

\begin{tabular}{|c|c|c|c|c|c|}
\hline & & $\begin{array}{l}\text { Glucose } \\
\text { in a } \\
\text { medium }\end{array}$ & $\begin{array}{l}\text { Initial } \\
\text { glycogen } \\
\text { content }\end{array}$ & $\begin{array}{l}\text { Increased or } \\
\text { decreased } \\
\text { glycogen cont. }\end{array}$ & $\begin{array}{l}\text { Glycogen } \\
\text { change } \\
\%\end{array}$ \\
\hline \multirow{3}{*}{ Glycogenolytic } & Control & 0.30 & 0.42 & -0.09 & -21.4 \\
\hline & Adrenalin $50 \mu \mathrm{g} / \mathrm{ml}$ & 1.20 & 0.42 & -0.18 & -42.9 \\
\hline & Control & 3.22 & 0.56 & -0.15 & -26.8 \\
\hline \multirow[t]{4}{*}{ environment } & Insulin $2.0 / \mathrm{ml}$ & 3.63 & 0.56 & -0.14 & -25.0 \\
\hline & Control & 3.22 & 0.56 & -0.15 & -26.8 \\
\hline & Adrenalin injection & $2 \cdot 78$ & 0.54 & -0.12 & -22.2 \\
\hline & Insulin injection & 1.82 & 0.62 & -0.22 & -35.5 \\
\hline $\begin{array}{l}\text { Glycogenetic } \\
\text { environment }\end{array}$ & $\begin{array}{l}\text { Control } \\
\text { Adrenalin injection } \\
\text { Insulin injection }\end{array}$ & $\begin{array}{r}-12.67 \\
-8.07 \\
-9.22\end{array}$ & $\begin{array}{l}0.76 \\
0.56 \\
0.57\end{array}$ & $\begin{array}{l}+0.29 \\
+1.70 \\
+1.79\end{array}$ & $\begin{array}{r}+38.2 \\
+303.6 \\
+314.0\end{array}$ \\
\hline
\end{tabular}

Glycogenolytic environment: medium $2 \mathrm{ml}, 0.4 \%$ pyruvate $+K$. R. B. solution

Glycogenetic environment: medium $2 \mathrm{ml}, 1 \%$ glucose+Buchanan and Hastings solution Pretreatment: Killed 1 hour after injection of adrenalin, $0.2 v$ per kilo $(1,000$ times) or insulin, 3 units per kilo

3) Effects of pituitary and cortical hormones

(a) Under the environment of glycogenolysis

Table 7. Influences of various hormones added into the medium - normal rat liver slices (mg per $\mathrm{gm}$ )

\begin{tabular}{lllll}
\hline \hline & $\begin{array}{l}\text { Glucose } \\
\text { in a } \\
\text { medium }\end{array}$ & $\begin{array}{l}\text { Initial } \\
\text { glycogen } \\
\text { content }\end{array}$ & $\begin{array}{l}\text { Decreased } \\
\text { glycogen } \\
\text { content }\end{array}$ & $\begin{array}{l}\text { Glycogen } \\
\text { change } \\
\%\end{array}$ \\
Control & 3.22 & 0.56 & -0.15 & -22.8 \\
Cortisone acet. & 4.17 & 0.55 & -0.11 & -20.0 \\
DOCA & 2.50 & 0.57 & -0.16 & -28.1 \\
ACTH & 1.42 & 0.57 & -0.19 & -33.3 \\
\hline
\end{tabular}

Glycogenolytic environment: medium $2 \mathrm{ml}, 0.4 \%$ pyruvate + K. R. B. solution

Table 8. Influences of pretreatment with various hormones - normal or alloxan diabetic rat liver slices ( $\mathrm{mg}$ per $\mathrm{gm}$ )

\begin{tabular}{|c|c|c|c|c|c|c|}
\hline & & $\begin{array}{l}\text { Glucose } \\
\text { appearance } \\
\text { in a medium }\end{array}$ & $\begin{array}{l}\text { Initial } \\
\text { glycogen } \\
\text { content }\end{array}$ & $\begin{array}{l}\text { Decreased } \\
\text { glycogen } \\
\text { content }\end{array}$ & $\begin{array}{l}\text { Glycogen } \\
\text { change } \\
\%\end{array}$ & $\begin{array}{l}\text { Blood } \\
\text { sugar } \\
\text { mg } \%\end{array}$ \\
\hline$\overline{0}$ & Control & 3.22 & 0.56 & -0.15 & -26.8 & 63 \\
\hline \multirow{3}{*}{$\begin{array}{l}\bar{L} \\
\bar{E} \\
\bar{O}\end{array}$} & Cortisone acet. & 14.66 & 19.09 & -13.88 & -72.7 & 149 \\
\hline & DOCA & 1.53 & 0.62 & -0.10 & -16.1 & 72 \\
\hline & ACTH & 1.40 & 0.53 & -0.16 & -30.2 & 75 \\
\hline \multirow{4}{*}{ 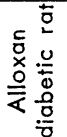 } & Control & 4.56 & 0.63 & -0.28 & -44.4 & 581 \\
\hline & Cortisone acet. & 10.45 & 23.64 & -15.35 & -64.9 & 212 \\
\hline & DOCA & 2.54 & 0.78 & -0.30 & -38.5 & 314 \\
\hline & $\mathrm{ACTH}$ & 6.34 & 0.87 & -0.19 & -21.8 & 418 \\
\hline
\end{tabular}

Glycogenolytic environment: medium $2 \mathrm{ml}, 0.4 \%$ pyruvate $+K$. R. B. solution Pretreatment: Cortisone, DOCA and ACTH each $5 \mathrm{mg}$ per body weight, was injected to normal rats for 7 days and alloxan rats for 4 days 
The appearance of glucose in the medium was definitely increased by cortisone, inhibited by DOCA and AGTH. Glycogenolysis was inhibited by cortisone, promoted by ACTH, but not influenced by DOCA, though those changes were not so remarkable.

Secondly pituitary or cortical hormones were injected prior to the experiments. Under the same condition of incubating medium, the glucose increased markedly in the medium in the case of the cortisone pretreated animals, either normal or alloxan diabetic; and there was a marked decrease in the amount of glycogen synthesized. With DOCA pretreatment, the glycogenolysis was somewhat prevented in both normal and alloxan diabetic liver slices. ACTH pretreatment caused an glycogenolytic effect in normal slices, but in alloxan diabetic liver slices, inhibitory effect was observed.

(b) Under the environment of glycogenesis

The effects of pretreatment with pituitary and cortical hormones on the glucose balance and glycogen synthesis are summarized in Table 9.

Table 9. Influences of pretreatment with various hormones - normal or alloxan diabetic rat liver slices ( $\mathrm{mg}$ per $\mathrm{gm}$ )

\begin{tabular}{|c|c|c|c|c|c|c|}
\hline & & $\begin{array}{l}\text { Glucose } \\
\text { in a } \\
\text { medium }\end{array}$ & $\begin{array}{l}\text { Initial } \\
\text { glycogen } \\
\text { content }\end{array}$ & $\begin{array}{l}\text { Increased } \\
\text { or decreased } \\
\text { glycogen cont. }\end{array}$ & $\begin{array}{l}\text { Glycogen } \\
\text { change } \\
\%\end{array}$ & $\begin{array}{l}\text { Blood } \\
\text { sugar } \\
\text { mg \% }\end{array}$ \\
\hline$\div$ & Control & -12.67 & 0.76 & +0.29 & +38.2 & 63 \\
\hline \multirow{3}{*}{$\begin{array}{l}\bar{\sigma} \\
\stackrel{\sigma}{E} \\
\text { o } \\
Z\end{array}$} & Cortisone acet. & -9.25 & 9.12 & -6.51 & -71.4 & 125 \\
\hline & DOCA & -11.81 & 0.67 & -0.08 & -11.8 & 70 \\
\hline & ACTH & -2.92 & 0.75 & +0.40 & +53.3 & 90 \\
\hline \multirow{4}{*}{ 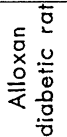 } & Control & -3.05 & 0.76 & -0.29 & -38.2 & 637 \\
\hline & Cortisone acet. & +8.13 & 21.45 & -10.30 & -48.0 & 222 \\
\hline & DOCA & +1.43 & 0.78 & -0.15 & -19.5 & 342 \\
\hline & ACTH & -3.32 & 0.66 & +0.76 & +115.2 & 280 \\
\hline
\end{tabular}

Glycogenetic environment: medium 2ml, $1 \%$ Glucose + Buchanan and Hastings solution Pretreatment: Cortisone, DOCA and ACTH each $5 \mathrm{mg}$ per gm body weight, was injected to alloxan rats for 4 days. and normal rats for 7 days

Cortisone caused a marked glycogenolysis in both normal and alloxan liver slices, in spite of the glycogenetic condition of the medium, while DOCA showed glycogenolysis in normal liver slices. However, the liver slices of the alloxan diabetic rat, when similarly treated, definite preventing action on glycogenolysis.

In the alloxan liver slices pretreated with ACTH, there were a great increase of glycogen, and a definitely increased glycogen in normal animals.

\section{DISCUSSION}

The influence of mesoxalate and various hormones on glycogenesis and glycogenolysis in normal and alloxan diabetic liver slices have been studied in vitro, and the results have shown the following characteristics; firstly when these substances were added into the medium, no marked changes on both glycogensis and glycogenolysis were found, however, the pretreatments with these substances 
have shown marked effect. Secondly, with prior injection of cortisone there appeared a marked glycogenolysis irrespective of the ionic environments, while as Baba has reported, with the pretreatment of cortisone the normal diaphragm produced a marked amounts of glycogen, and lastly that, according to the results of the present experiment and the report of Baba, the behavior with ACTH pretreated liver slices and diaphragm on the glycogen synthesis is most similar to those of adrenalin.

It is to be noted that the liver slices of the animals previously treated with mesoxalate and various hormones were found to be very effective to the glycogenolytic reactions, the similar result was observed by Baba, using surviving diaphragm. Particularly interesting fact would be that the formation of glycogen with cortisone pretreated instances showed the discrepancy between the diaphragm and liver slices, and it is therefore of important to reveal the mechanism of this difference.

It is not possible to state whether this discrepancy of liver and diaphragm on glycogen formation is due to the altered ionic composition of surviving tissues or the results of altered activity of enzymes by the disturbed endocrine balance of tissues following previous injection of cortisone, to this question the study is under way.

It is also interesting to compare the data on the effects of mesoxalate and various hormones in liver and in diaphragm slices, and it was found that the synthesis of glycogen in the previously ACTH treated liver slices or diaphragm has shown the similar results as obtained with adrenalin or insulin pretreated rat, and these are summerized in Table 10.

Table 10.

\begin{tabular}{|c|c|c|c|c|c|}
\hline & \multicolumn{4}{|c|}{$\begin{array}{l}\text { Normal Liver Slices with Adrenalin, } \\
\text { Insulin or ACTH pretreated. }\end{array}$} & \multirow[t]{2}{*}{$\begin{array}{l}\text { Normal Diaphragm with } \\
\text { Adrenalin, Insulin or } \\
\text { ACTH pretreated. }\end{array}$} \\
\hline & $\begin{array}{l}\text { Under the } \\
\text { environment }\end{array}$ & glycogenolytic & $\begin{array}{l}\text { Under the } \\
\text { environment }\end{array}$ & glycogenetic & \\
\hline & $\begin{array}{l}\text { Glucose } \\
\text { appearance }\end{array}$ & $\begin{array}{l}\text { Glycogen } \\
\text { formation }\end{array}$ & $\begin{array}{l}\text { Glucose } \\
\text { disapp. }\end{array}$ & $\begin{array}{l}\text { Glycogen } \\
\text { formation }\end{array}$ & $\begin{array}{l}\text { Glycogen } \\
\text { formation }\end{array}$ \\
\hline Adrenalin & decreased & no change & decreased & $\begin{array}{l}\text { increased } \\
\text { great degree }\end{array}$ & decreased \\
\hline Insulin & $\begin{array}{l}\text { marked } \\
\text { decreased }\end{array}$ & decreased & decreased & $\begin{array}{l}\text { increased } \\
\text { great degree }\end{array}$ & increased \\
\hline ACTH & decreased & no change & decreased & increased & decreased \\
\hline
\end{tabular}

It is clear from the Table 10 that the pretreatment of ACTH and adrenalin show the similar effects on the glycogen formation in liver or in diaphragm, and that insulin does not show such exact similarity.

\section{SUMMARY}

1) The influence of mesoxalate and various hormones, when added into the medium or administered to the animal previously to the experiments, on the glucose balance of the medium and glycogen formation in liver slices under 
the glycogenetic and glycogenolytic ionic environments of the incubating medium were investigated.

2) Under the glycogenolytic environment, the addition of mesoxalate or mesoxalate with insulin into the medium caused a slight decreased or no effect on the glycogen synthesis in normal and alloxan liver slices, while, under the glycogenetic environment the added mesoxalate showed an increased effect in normal animal, while decreased effect on the glycogen synthesis in alloxan.

3) Daily administration of mesoxalate previous to the experiment, resulted in an inhibition against glycogenolysis - somewhat for the normal and more for the alloxan animal. A marked decrease in the glucose appearance into the medium was found under the glycogenolytic condition and under the glycogenetic condition there were marked increased glycogenesis in normal liver slices.

4) Under the glycogenolytic ionic composition, the addition of insulin or adrenalin into the medium, which was shown to be inhibitory on the glycogen formation, caused no definite effect in the case of adrenalin pretreatment, and a depressive effect in insulin pretreatment on the glycogen formation, whilst under the condition of glycogenesis large amounts of glycogen were produced in the slices with insulin or adrenalin previously injected.

5) No change or certain glycogenolysis took place by the addition of DOCA or ACTH into the medium, and glycogenolysis was inhibited by cortisone.

In the experiment of the pretreatment with cortisone under the glycogenolytic or even under the glycogenesic environment a marked glycogenolysis was seen in both the normal and alloxan liver slices.

With ACTH pretreatment a marked promoting effect on the formation of glycogen was observed under the glycogenetic condition in alloxan and somewhat less in normal liver slices were seen.

6) It is interesting to compare these results on the liver slices with those on the diaphragm; two particular points were observed, firstly the results on glycogen synthesis in the liver slices and diaphragm of the ACTH pretreated animal were quite similar to the result on the one of the adrenalin pretreated: secondly, in the animals pretreated with cortisone a definite discrepancy on the glycogen formation was observed between the liver slices and diaphragm.

This work was partly supported by the Grant in Aid for Experimental Scientific Research from the Ministry of Education.

\section{REFERENCES}

Baba, S. (1956). Endocrinol. Jap. 3. 40.

Bendall, J. R, and H. Lehmann (1942). Biochem. J. 36, Xiv.

Buchanan, J. M., A. B. Hastings and F. B. Nesbett (1949). J. Biol. Chem. 180, 435.

Chiu, C. Y. and D. M. Needham (1950). Biochem. J. 46, 114.

Chiu, C. Y. (1950). Biochem. J. 46, 120.

Gey, G. O. and M. K. Gey (1936). Am. J. Cancer 27, 45.

Good, C. A., H. Kramer, and M. Somogyi (1933). J. Biol. Chem. 100, 485.

Hagedorn-Jensen (1923). Biochem. Zs. 135, 46, Ibid. 137, 92,: (1924). Ibid. 140, 538.

Krebs, H. A. and K. Henseleit (1932). Z. physiol. Chem. 210, 33.

Norikane, C. (1942). Mitt. M. Akad. Kioto, 36, 527.

Ostern, P., D. Herbert and E. Holmes (1939). Biochem. J. 33, 1858.

Seckel, J. (1940). Endocrinology 26, 97. 